\title{
CREATING CULTURALLY-SAFE SCHOOLS for MĀORI STUDENTS
}

\section{ANGUS MACFARLANE ${ }^{1}$ TED GLYNN ${ }^{1}$, TOM CAVANAGH ${ }^{1}$ \& SONJA BATEMAN ${ }^{2}$}

1 School of Education, University of Waikato, Private Bag 3105, Hamilton, 3240, New Zealand

2 Ministry of Education, PO Box 774, Hamilton, 2001, New Zealand

\section{Abstract}

In order to better understand the present trends in New Zealand's schooling contexts, there is a clarion call for educators to develop sensitivity and sensibility towards the cultural backgrounds and experiences of Mãori students. This paper reports on the work of four scholars who share research that has been undertaken in educational settings with high numbers of Mãori students, and discusses the importance of creating culturally-safe schools - places that allow and enable students to be who and what they are. The theoretical frameworks drawn on are based on both a life partnership analogy as well as on a socio-cultural perspective on human development and learning. The Māori worldview presented in this paper is connected to the Treaty of Waitangi, The Educultural Wheel and the Hikairo Rationale. Data were collected from two ethnographic case studies and analysed through these frameworks. Practical suggestions are then made for using restorative practices and creating reciprocal relationships in classrooms within an environment of care. The paper reports on an evidence-based approach to creating culturally-safe schools for Māori students.
Introduction

All students benefit from being in a culturallyinclusive classroom. However, many students from non-dominant cultures are not free to be whom and what they are when they go to school. This paper presents ideas for creating culturally-safe schools; that is, schools that are inclusive environments for Mãori students - indeed all students. Mãori are the tangata whenua (Indigenous people) of Aotearoa (New Zealand). This paper draws on the work of four scholars in the field of multicultural education and attempts to address the question of how to create culturally-safe schools for Mãori students. Much of the background for this paper emanates from the work of the Ministry of Education Poutama Pounamu Research Centre, in Tauranga, in the Bay of Plenty region in the North Island of Aotearoa New Zealand. This centre was formed in the early 1990s by a group of Māori kaumàtua (men and women elders) from several tribes in the region, (Ngāi te Rangi, Ngāti Ranginui, Ngāti Pūkenga, Ngāi Tūhoe, and Ngāti Awa), who were all concerned to improve the educational achievement of Māori students in local schools. Ted Glynn, a Pākehā (person of European ancestry) educational researcher, was invited to join the group, which operates along the lines of a whänau (extended family), and was given the name Poutama Pounamu by the elders involved. Angus Macfarlane adds a perspective to that framework from a Mãori worldview. Based on his international ethnographic research on schools as safe communities, Tom Cavanagh offers some practical ideas for creating culturally-safe schools. Sonja Bateman explains how these concepts and practices inform the professional development initiatives of the Ministry of Education (Group Special Education) staff.

\section{Theoretical framework}

The theoretical framework for this paper stems from a life partnership analogy (Glynn et al., 2001) based on the notion that what we know and understand about conducting personal partnerships in life can guide us in establishing effective working partnerships with others. The analogy draws on the destructive outcomes that can occur within life partnerships, where one partner holds a far more powerful and dominant position within the partnership than the other. Such partners can claim to speak for and on behalf of the weaker partner; to know what the weaker partner 
thinks, feels and needs; to know what the appropriate remedies are to solve problems. Such partners often abuse the power they have by imposing their perceived remedies on the less powerful partner, with little or no consultation. Sometimes they resort to undue force in doing this. Such partners may decide unilaterally that the partnership has ended. This partnership analogy both highlights problems and suggests solutions. Two possible solutions emerge: to end the relationship or to restore the relationship.

Fundamental to this framework is the idea that often educators who are members of the dominant and more powerful culture may hold impositional attitudes towards students who belong to non-dominant less powerful cultures, and towards their ethnic and cultural communities. This mode of thinking is a key factor in the subsequent performance of those students as it causes educators to focus on less positive indices in terms of Māori achievement. Such modes of thinking are illustrated in these statements:

- "They're that sort of person"

- "They're not very bright"

- "It's just a peculiar minority"

- "It's their age"

- "This is a difficult neighbourhood" (Watkins \& Wagner, 2000, p. 3, cited in Wearmouth et al., 2005).

Taking such positions locates the entire problem with the students and their communities. There is no space for considering that problematic student behaviour might have resulted from interactions within the classroom, and that perhaps it is the ecological environment that needs to change.

Socio-cultural theory of human learning and development (Bronfenbrenner, 1979; Bruner, 1996; Glynn et al., 2005; McNaughton, 2002; Vygotsky, 1978) is grounded in a number of important understandings. One of these is that interpersonal and intellectual learning are interdependent from birth and continue to remain so throughout life. Cognitive and intellectual development result not from acquiring generic literacy skills, for example, but from engagement in particular literacy practices through interaction with others in social situations (Scribner \& Cole, 1998, cited in Wearmouth et al., 2005). This view contrasts with many traditional Western views of human learning and development in which learning and cognition were seen as largely independent of the different influences of particular social contexts and environments. Another important feature of socio-cultural approaches to learning and development is that

children are seen as assuming autonomy over their own learning, and as entering into learning interactions, activities and routines, and developing social relationships with more skilled members within their cultural communities (Wearmouth et al., 2005, p. 2).

Glynn, Wearmouth and Berryman (2005) note that students may not succeed in their learning at school if certain literacy practices are privileged over others, for example when students' literacy achievements in family, home and community contexts are neither acknowledged nor affirmed in the literacy practices of the classroom and school. When this happens, teachers are challenged to find ways of including students from different social and cultural backgrounds into the community of practice in their classrooms. Further, in many schools teachers may have so little authentic knowledge and experience of the family and community contexts in which their students live that they are unable to participate in those literacy contexts and practices in which their students are already successful. They are unable to give sufficient agency to these students in co-constructing classroom routines and learning opportunities. From a socio-cultural point of view, therefore, how teachers and schools understand as well as how they respond to students with challenging behaviour and learning difficulties is critical. This will require them to examine and modify the way they engage and interact with their students and the pedagogical practices they employ (Macfarlane \& Bateman, 2005).

Connections to a Māori worldview

\section{Treaty of Waitangi}

In 1840, Lieutenant-Governor Hobson and Māori chiefs signed the Treaty of Waitangi on behalf of the British Crown and the Mãori people, and their descendants. Under Article 1 of this Treaty, Mãori ceded kawanatanga (governorship or administrative control) to the Crown. Under Article 2, the Crown ceded to Māori rangatiratanga (chiefly control or selfdetermination) over their lands, forests and fisheries and other taonga (treasures or resources). Mãori also retained their sovereign rights to define, promote and control those treasures and resources, which include the creating, retaining and transmitting of language and cultural knowledge. Under Article 3 of the Treaty, Māori were guaranteed the full rights of British citizenship. Māori have long regarded the Treaty of Waitangi as a charter for partnership and power-sharing in the decision-making processes of government, for selfdetermination as Indigenous people, and as a guide to intercultural relations within Aotearoa New Zealand.

However, the relationship between Mãori and Pākehā (people of European ancestry) in Aotearoa New Zealand has not been characterised by partnership and power-sharing, but rather by political and social domination by the Pākehā majority. This domination 
progressed through armed struggle, unjust confiscations of land, biased legislation and successive educational policies and initiatives that have imposed Pākehã language and knowledge to the detriment of Mãori language and knowledge. Government educational policies have ranged through assimilation, integration, multiculturalism and biculturalism. The cumulative effects of these successive policies has been to require Mãori to sacrifice more and more of their language, culture and their own Indigenous educational aspirations to the needs and goals of the nation, as determined largely by the Pākehā majority. Participation in mainstream education in Aotearoa New Zealand has come for Māori at a cost of their own language and culture.

When educational policies in Aotearoa New Zealand succeed in addressing the principle of protection embedded in Article 2 of the Treaty, and allow Mãori to exercise their rights to define and develop curriculum and pedagogy that will protect their knowledge, language, values, beliefs and practices, the scene will be set for schools that will be culturally-safe for Māori students and their families.

\section{"The Educultural Wheel"}

Macfarlane's (1997, 2004) work offers a framework for creating a Māori perspective in schools. Bishop and Glynn (1999) are consistent with Macfarlane in identifying whakawhanaungatanga (the process of building relationships) as a key tikanga (culturallyresponsive approach) for improving behaviour and learning outcomes for Mãori students. The five concepts that form "The Educultural Wheel” (Macfarlane, 2004) which support this notion are outlined below:

\section{Whanaungatanga (relationships)}

This concept proposes establishing relationships in a Mãori context based on kinship, common locality, and common interests. Teachers can engage in this whanaungatanga by getting to know each student as an individual, and by generating opportunities to build mutual trust and respect. It is also important for the students to learn something about the teacher's interest and concerns. This process should begin in the first week of school. Teachers are encouraged to use cooperative learning strategies, to involve parents and families in the classroom, and to engage the support of community people as resources.

\section{Rangatiratanga (self-determination)}

Rangatiratanga refers to becoming an effective and competent teacher. Developing skills, gaining knowledge, and working diligently, are significant expressions of rangatiratanga. Teachers with mana (integrity and dignity) possess a demeanour of dignity and respect, and recognise and develop the mana of the child, particularly in the way they interact with them. Teachers are encouraged to scan the classroom, to use antecedent behaviour management strategies such as effective body language, making eye contact, using physical proximity, displaying confident demeanour and assertiveness. This approach is more effective that relying on aversive control to reduce or eliminate unacceptable classroom behaviour.

\section{Manaakitanga (etbos of care)}

Manaakitanga is a concept that embodies a type of caring that is reciprocal and unqualified, based on respect and kindness, a "duty of care". Teachers are encouraged to adopt an ethic of care in their classroom in order to establish cultural connectedness.

4. Kotahitanga (unity and bonding)

Kotabitanga is a concept that advocates becoming one out of many, where a sense of unity and inclusiveness is created within the classroom and school by recognising everyone's mana. Teachers are encouraged to establish relationships with students person-to-person, to give awards to the class as a community, to engage in rituals or routines such as a morning mibi (culturally appropriate greetings) and after school activities, including support with homework. Teachers are also encouraged to explore and operate by the underlying principles of partnership, protection and participation as represented within the Treaty of Waitangi. These principles may then serve as a basis for a class treaty of power sharing through exercising reciprocal rights and responsibilities.

The school, too, is encouraged to engage in schoolwide activities that will help build school communities that are culturally-safe for students from minority cultural groups. Examples of these activities include Te wiki o te reo Māori (Mãori language week), and the use of Te hui whakatika (meeting to make amends and restore calm). Te hui whakatika is a process of putting things right after wrong-doing has occurred, and has similarities to contemporary restorative justice group conferencing (Hooper et al., 1999). This is an effective alternative to the deficit thinking that focuses on punishment, such as the suspension or exclusion of individuals.

\section{Pumanawatanga (a beating beart)}

This concept involves pumping life into the other four concepts and sustaining their presence. Teachers are encouraged to adopt a position within their classrooms that is consistent with these concepts, and evidenced in their values, beliefs, attitudes and behaviour. The school, too, is encouraged to develop an infrastructure of care and support for 
students and teachers that are consistent with these concepts.

The Hikairo Rationale

The Hikairo Rationale is a bicultural approach to working with students who present with challenging behaviour and was developed by Macfarlane (1997) out of a concern that Western theorising tended to dominate the field. This approach focuses on wholeness of taba tinana (body), taba binengaro (mind), and taba wairua (spirit), within the taba whänau (family), and draws on Durie's (1994) Whare Tapa Whā model of holistic well-being. The Hikairo Rationale incorporates Māori and Western concepts and values. The core concept within the Hikairo Rationale is aroba or love in all its different aspects such as compassion, empathy, responsiveness and concern). The Hikairo Rationale encompasses seven domains:

\section{Huakina mai (opening doorways)}

Establishing meaningful relationships with students by creating positive expectations for student behaviour through modelling, shared experiences, and making connections in a proactive way.

\section{Ibi (assertiveness)}

Setting clear boundaries that are fair and consistent, expressing respect for personal dignity, and making constructive use of learning opportunities, as they occur.

\section{Kotabitanga (unity)}

Relying on decision-making by consensus through discussion, encouraging cultural identity through the curriculum, and transferring tikanga values, such as baere tabi (progressing together), mabi tabi (working together), nobo tabi (staying together), into the classroom. Bateman (2003) offers an example of a resource, Te Kupenga o te Manaaki (support network), that demonstrates how the concept of kotabitanga can be manifested in a classroom context by infusing the above cultural values in the assessment of Māori students.

\section{Awbinatia (belping process - interventions)}

Creating a collaborative classroom climate where individual dignity is highly valued, where teachers believe in students' abilities to learn, and where classroom norms and routines are clearly explained. Teachers reach out with genuine caring and respect for their students, even for those who have been engaged in wrongdoing, while students realise that the realities of their lives and beliefs may be different from that of their teachers.

\section{I runga $i$ te manaaki (pastoral care)}

Creating a school culture of support, caring, and understanding, based on the concepts of tika (fairness), pono (integrity), and aroba (compassion). Cavanagh (2004) has observed that it is not supportive teachers that we lack, but rather supportive schools that nurture and support those teachers.

\section{Raranga (weaving process)}

Together the student, teacher, and whänau see themselves as being collectively responsible for understanding and overcoming challenging behaviours in the classroom, school and community. An example of such a collaborative approach to behaviour management is found in the Hei Awhina Mãtua (helping parents) programme involving students, teachers and community (Glynn, Berryman \& Atvars et al., 1997; Glynn, Berryman \& Bidois et al., 1997).

\section{Oranga (a vision of wellbeing)}

Drawing on the work of Glasser (1975) this domain considers the notion of progressing in four ways: (1) giving and receiving love; (2) achieving self-worth in own eyes and eyes of others; (3) having fun; and (4) becoming self-disciplined.

While the seven domains of the Hikairo Rationale overlap and interweave, each is characterised by concepts and principles that can be applied, firmly and democratically, through culturally-responsive teaching. The Hikairo Rationale unabashedly promotes the role that culture plays in the lives of people, and the implications of that role for those working with Mãori students and their whànau.

Data sources and methodology

As part of a research project for his Fulbright fellowship in Aotearoa New Zealand, Cavanagh (2004) was inspired to employ the frameworks of socio-cultural theory and a Māori worldview to collect and interpret the data. His ethnographic case study was in a small public rural area school (primary and secondary) in Aotearoa New Zealand, and was a replication of his dissertation study conducted in a private elementary school in the United States. fifty percent of the students in the Aotearoa New Zealand school identified as being Māori. Both studies involved the researcher in spending an extended period of time (over 400 hours) in each school interacting with students, parents, teachers, administrators, and community members.

Developing a methodological framework for the research undertaken in this case study helped provide a lens for deciding what data to collect from whom and making sense of and understanding the data collected 
in the field. Methodologically this is consistent with kaupapa Mãori educational research (Bishop, 2005; Bishop \& Glynn, 1999). This culturally-responsive kaupapa Māori approach provided guidance for who made decisions, how they were made, and when. This approach allowed for researchers and research participants to critically reflect on their positioning relative to five critical issues (Bishop, 1996) initiation, benefits, representation, legitimation, and accountability - and evaluate power relations before and during the research study. These relationships were considered crucial to the underlying purpose of the research.

Constructing ethical relationships was the key to how Cavanagh (2005) actualised this methodological framework in the field. Using a constructivist methodology, he was motivated to develop a relationship with participants that helped to represent their multiple voices in a way that was authentic and genuine. Acting as a "passionate participant," the aim of Cavanagh's study was to seek understanding and attempt to reconstruct the multiple voices that were part of the enquiry. After each set of data was collected and analysed, participants were asked for their comments. This approach required that the researcher listen to staff and students and to reflect on the different perspectives people held. This choice encouraged the participants to talk openly about tensions at the school and raised awareness of the school community about those tensions. As a result, the Māori concept whakawhanaungatanga, which refers to building collaborative relationships in the research setting in order to accurately represent the voices of the people, took on a deeper and more purposeful meaning (Bishop \& Glynn, 1999).

The Aotearoa New Zealand study involved collecting data in the form of field notes, formal and informal conversations, focus group interviews with students, staff, and parents, documents, and journal entries. Data were analysed using constructivist grounded theory and vignette writing, and reflective memos were shared with the participants seeking their comment. This approach was chosen to add credibility and trustworthiness to the project.

\section{Findings}

Cavanagh's project, carried out in Raglan Area School (Cavanagh, 2005), emphasises the need to realise that schools are complex and dynamic organisations. They reflect and are a microcosm of our society. Nowhere else in society do the different dimensions of culture come together in such a small space. We can expect differences and should support, encourage, and celebrate those differences, never allowing one perspective to dominate over another. The tensions resulting from these differences are not altogether unusual and can provide the motivation for improving the intercultural understandings and communications within the school.

The primary findings from this study show relationships to be the core element for a culturally-safe ethos within the school. The key groups involved in relationships are students, parents, families, teachers, administrators, and community members. The central activities of relationships are explained in terms of three constructs: restorative practices, relationshipsbased classroom pedagogy, and a culture of care. The glue that holds a school together is an ambiance or atmosphere of care, which combines rituals, relationships, and community. The Māori concepts of manaakitanga, kotabitanga, and rangatiratanga, as described by Macfarlane (2004) in the Educultural Wheel provide the connecting links between the three areas described (see Figure 1).

Culturally-safe schools

In answer to my question about what it is like to be a Māori student in senior school, the student replies, "Most of the time the lights are turned off. The light comes on Tuesday afternoon at kapahaka (Māori performing arts group)" (Fieldnotes, 28 October, 2004).

A new definition of "safety" emerged from this study. From a Mãori cultural viewpoint, safety is taken to mean freedom to be who (individually) and what (collectively) we are. From the field experience Cavanagh (2005) learned that Mãori students need to feel respected and proud of who and what they are as Māori. Teachers and all school personnel need to respect the Mãori preferred ways of learning, whänau wisdom, and karakia (prayer). Māori preferred ways of learning include acknowledgement, celebration, mentoring, and honouring an individual's Mãoritanga (Māoriness). Senior Māori students' culture can be validated by allowing them to express themselves in different ways, utilising whole-brain learning strategies, celebrating differences, and developing a deep respect for these students. The key to this process is knowing who to ask and what to ask about tikanga Māori (values, beliefs and practices held by Māori people).

\section{Relationships (Whanaungatanga)}

Community is a safe and friendly environment where people live in healthy relationships based on caring and support in a family atmosphere; a place where everyone knows and looks out for each other and their surroundings in an atmosphere of bonding of everything and everyone (Fieldnotes, 8 October, 2004). 


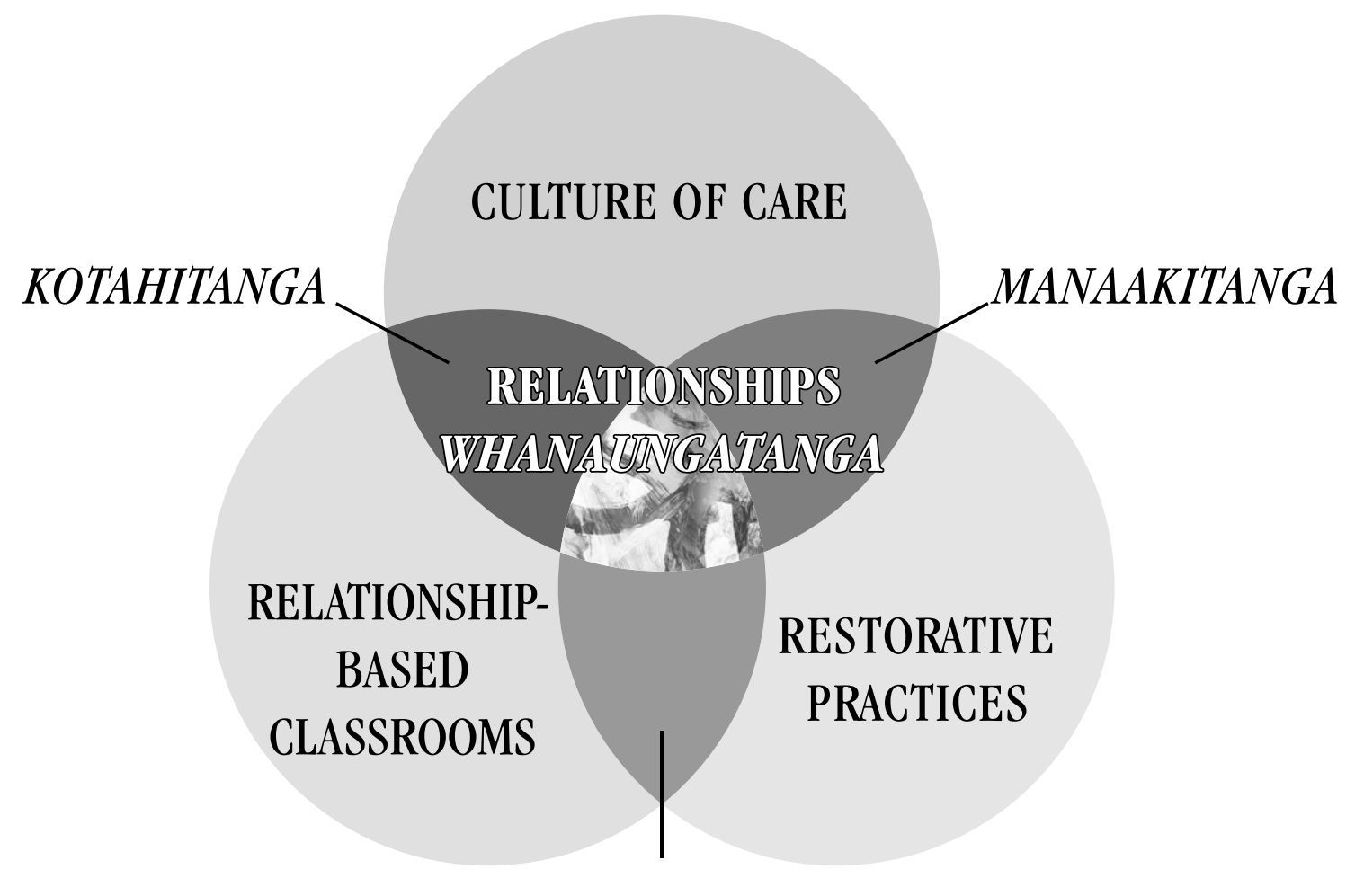

RANGATIRATANGA

Figure 1. Creating culturally-safe schools for Māori students.

The primary theme emerging from this core idea of creating a culturally-safe school is relationships. Relationships are the key to a successful school and a key motivator for students. The findings made it explicit that relationships among teachers and staff should involve appreciating, supporting, valuing, and encouraging each other to share talents, expertise and knowledge in a non-judgmental manner of collegial sharing and tolerance for differences. Ideally, relationships with students should focus on welcoming each student, developing a personal rapport with them early in the school year, helping each child to feel successful about their learning, seeing themselves as successful learners from the beginning of school to the end, treating them fairly in an open and honest manner, giving them feedback, and making it fun.

Restorative practices

"Although they are rough around the edges, in their hearts the students do care", quoting a teacher (Fieldnotes, 6 August, 2004).
The second theme emerging from the research is restorative practices. Restorative practices typically respond to wrongdoing by striving to restore the mana of all those affected by the wrong, those harmed by the wrongdoing, those causing the harm, and their families and communities. Such practices are readily understood within a Māori worldview with its emphasis on collective identity and responsibility. While restorative practices in Aotearoa New Zealand are often equated simply with conferencing, Cavanagh contends that three key elements underpin the philosophy of these practices: safety, accountability, and competency. Safety means freedom from harm and the threat of harm. Accountability means taking responsibility to heal the harm to relationships resulting from wrongdoing. Competency is learning from an incident of wrongdoing how to choose to act differently in the future.

The work of Hooper et al., (1999), Macfarlane (2004) and Wearmouth, McKinney and Glynn (in press), provide Aotearoa New Zealand examples of restorative practices in action, in the context of school and community responses to the challenging 
behaviour of Māori students. These examples demonstrate how to avoid merely assigning blame and punishment to individuals, and focus instead on how to put things right and restore the mana of all those involved. However, these examples show also that such restorative practices were not owned and controlled by schools alone. Rather, they were owned by Māori iwi (tribe), bapū (sub-tribe), whānau and students, and managed in partnership with schools and communities.

Conversations with parents revealed that bullying was a major safety issue at the school in this study. The parents were concerned when bullying occurred to their child; they were pleased when the school responded quickly to address the situation. Apologies are a major component of healing relationships. Helping students learn to offer sincere apologies is often difficult if they were taught at home not to express their emotions or to say they are sorry. Teachers need to work with students to help them to acquire this skill as this is a crucial element of healing the harm to relationships.

The school and classroom rules that Cavanagh observed emphasised respect in three areas: person, property, and the environment. These observations are consistent with the notion of Noddings (2002), that respect or care for the environment in our community is an important element of creating caring people. They are also very consistent with showing respect and caring for Papatuanuku (mother earth), a central value and practice within Māori culture.

\section{Relationships-based classrooms}

One staff member's philosophy of teaching: "Children want to learn, so find out what they want to learn and remove the barriers to their learning. Keep them safe" (Fieldnotes, 19 October, 2004).

Relationships-based classrooms are whänauoriented and involve the whänau. They are placebased, constructivist, personalised, and encourage role models and mentorship (tuakana-teina). A whänau-oriented classroom empowers students to participate in creating a learning environment based on reciprocal relationships between the teacher and students and students with students. Involvement of the whanau in the classroom is based on trust. For whanau to feel welcome in the classroom they need to feel welcome at anytime, have an authentic role to play in the programme, and be allowed to have spiritual involvement.

Bishop, Berryman, Cavanagh and Walker (2006) explain that the project commenced in 2001 and sought to address the self-determination of Year 9 and 10 Mãori secondary school students by talking with them as well as teachers, principals and whänau about just what happened to limit and/or improve their educational achievement. From these narratives of experience, the project developed an Effective Teaching Profile, which identifies understandings and practices that will assist Mãori students to achieve to their potential in mainstream classrooms. The project seeks to implement this Effective Teaching Profile by creating a culturally-appropriate and responsive context for learning in classrooms, through the development of a pedagogy of relations. This development is undertaken through a process which promotes the pedagogies both within classrooms and beyond classrooms. According to Penetito (2004), place-based education occurs outside the classroom, and mainly in the communities within which the students live. This type of education helps students to become aware of their roles within the community, gain hands-on learning and experience, and also increases their awareness of the world around them. This study identified that place-based education was happening for the students.

Te Kotahitanga (Bishop et al. 2006) is a research/ professional development project that aims to improve the educational achievement of Māori students in Aotearoa New Zealand through operationalising Māori people's cultural aspirations for selfdetermination within non-dominating relations of interdependence. Te Kotahitanga exemplifies how to create a relationships-based classroom founded on a kaupapa Māori solution (a solution determined by Māori, based on Māori values, beliefs and practices to the educational crisis that is currently facing Māori students in mainstream educational settings. In this sense, the project is informed by a kaupapa Māori theory of self-determination.

Constructivism is a teaching philosophy consistent with the position taken in this paper that is based on finding out and honouring what students can do, valuing their work, honouring the whole person, having high expectations, and bringing a lot of heart to the classroom. Constructivist classrooms are co-constructed and collaborative and involve an holistic approach based on collective learning, shared responsibility and shared ownership of the classroom. In these classrooms deep learning takes place because there is the opportunity for doing things differently, creativity is honoured, and students are allowed to be who and what they are. These classrooms are student-driven when students are free to be themselves. They are learning-centred when the teacher is a friend and has an equitable relationship with the students. Teachers can create personalised classrooms by developing a rapport with students early in the school year, being transparent, offering individual attention, and using "I" statements. During this study, it was observed that in a relationships-based classroom students are encouraged to be role models for their peers and younger students by mentoring, 
intervening when misbehavior is occurring, and assuming leadership roles. Because this idea is based on the tuakana-teina (cultural role of the older being responsible for the younger) model, it is linked to the whänau orientation of the classroom and school.

Culture of care

We would love you to tell all the tamariki ... they showed excellent manaakitanga (caring) to everyone through their waiata (song) and haka. The school truly reflects our community and whānau by ... biculturalism and whanaungatanga (relationships) strengths ... you are a great example to heaps of schools around Aotearoa (New Zealand) (From letter dated 22 November, 2004).

Cavanagh's initial research in America resulted in a theory of a culture of care for schools. This theory was based on the elements of rituals, healthy relationships, and community. Similar themes emerged from the Aotearoa New Zealand rural area school study. It was clear from both studies that an ambiance or atmosphere of care is central to creating a safe school.

\section{Rituals}

Rituals at the school were seen to be framed in the context of providing manaakitanga (hospitality) to guests. Both Mãori and Pākehā traditions formed the basis for the ritual of providing hospitality to guests. The Māori traditions of powbiri (formal welcome) and whakatau (informal welcome) for guests, and providing koha (gifts) to special guests (like student teachers and returning students), were an integral part of school life. Karakia in Māori was often shared at the beginning and end of meetings and gatherings. The English tradition of morning or afternoon tea was also a well-established ritual at this school. Whenever guests were present, kai (food) was provided by staff, parents, and students. Through these rituals the students learned the value of hospitality. Just as care is an exchange process - learning to care for and about others and how to respond appropriately to care - hospitality in the Mãori tradition is a reciprocal process - providing hospitality to guests, expecting to be treated with hospitality when visiting these guests.

\section{Relationships}

This study identified the importance of schools building student competency in creating and maintaining relationships. Student choice, peer support and respect were the major themes found in this area. Students need to be offered choices when misbehaviour occurs. Such choices help them to learn from their mistakes and to make better choices in the future. Peer support, among the teachers as well as among students is necessary for building healthy relationships. The study found that it was important to understand how teachers asked one another to cover duty for them, how a teacher sent a student to another classroom for time out, and how teachers spent time with one another socially. The students too were encouraged to support one another when they were injured and when they were being disciplined. Older students helped the younger ones with projects.

\section{Community}

The findings demonstrated that the concept of community meant there is a place for everyone. Solidarity or "all for all" at the school meant that once a student was part of the school whänau (regarding the school operating as an extended family) every effort was made to ensure there was a place for the student - a place to learn and a place to create healthy, positive relationships. Being bilingual and bicultural contributed to cultural safety in this school. Although the English language dominated, there was respect for te reo Mãori (language) and tikanga Māori (culture). The school offered students many choices and was flexible in providing alternatives that responded to students' individual learning styles and needs. Another key attribute of this school was its small size. Ark (2002) reports on evidence that small schools experience less violence than larger schools. Where there is less violence there is a greater chance of establishing a caring community, but this does not preclude larger schools succeeding in this respect. Another important component of a culture of care in schools is continuity, and one of the main advantages of an Area School like the one in this study is combining students from primary and secondary years on one campus. While some people may see that as a disadvantage, the continuity of this process, particularly transitioning from primary to intermediate and intermediate to secondary school is a great advantage for students. Another advantage of the Area School is the older students can be a buddy or mentor to younger students (tuakana/teina), modeling appropriate behaviour and tutoring them in their learning.

\section{Conclusions}

Creating a culture of care in schools - culturallysafe classrooms and culturally-safe schools - involves challenging and reviewing the systemic processes and practices that exist. Education for students within classrooms and schools in Aotearoa New Zealand must be responsive to the learning needs and cultural values of those students: A well known whakatauki (Māori proverb) Kia kite, kia matau, i Te Ao Mäori, ma te reo clearly espouses the message that it is only through exposure to and awareness of Māori culture and 
language that an understanding of a Mãori worldview - or what it means to be Māori - will develop. Holmes (1982) declares that cultures and languages which are regarded as useful or prestigious are more likely to be accepted and promoted by those in positions of power. Given that one's own culture and language reflects personal identity and self-worth, then it follows that school systems and programmes which are reflective of and responsive to the culture and language of Mãori will be espousing a clear message about how Māori students and their whänau are perceived. Conversely, as stated by Macfarlane (1998), the continuation of a dominant and mono-cultural classroom delivery will essentially serve to perpetuate the underachievement of Māori students within mainstream education.

For many schools, creating a culture of care would initially require them to encourage and support their teachers to learn more about things Mãori, to explore Māori concepts and perspectives, and to ultimately infuse this knowledge into their interactions with students. At the classroom level it would require teachers to focus on the classroom culture and practice, specifically drawing from the principles of the Treaty of Waitangi, in deciding how a culture of care may be established. Building a positive classroom culture is contingent on students having input and being included in determining the cultural boundaries and guidelines as embodied within the concept of tino rangatiratanga (self-determination). Bird and Drewery (2000) outline the significance of the four domains of Durie's (1994) Te Whare Tapa Wh (extended model of wholeness), and explore the implications of these four domains for Mãori students in classrooms. This paper proposes that classroom routines and programmes need to reflect these fundamental domains in order to progress educational and social development for Māori students.

Rangihau (1975) describes the essence of learning as a Māori in a Māori world, and reflects on the importance of group dynamics in achieving selfconcept and a desire for learning. The employment of such strategies as cooperative learning and peer tutoring should therefore be considered as preferred options for teachers when tailoring programmes. The need to ensure that programmes acknowledge, reflect and respond to Māori-preferred learning styles should also be understood and operationalised by teachers. Metge (1984), references eight aspects of learning which best meet the needs of Mãori students. Holistic, group and oral/aural aspects are predominant in effective learning strategies. Cathcart (1994) outlines the importance of linking the culture of home and school, by incorporating specific cultural activities into the classroom programme as well as within the ethos of the school. These activities are reflective of many of the aspects referenced by Metge and include contextual practices preferred by Mãori, namely the use of rhyme, rote and patterning. Macfarlane (2000) discusses comments made by Makereti who describes Mãori as a culture putting the people before the self, and further outlines the importance of whanaungatanga. The importance of sharing, consultation, collaboration and participation should not be underestimated. When such processes and concepts are embraced by teachers and schools, then strong cultural links are more meaningfully secured, leading to the likelihood of enhanced educational outcomes for Māori students.

The Hikairo Rationale (Macfarlane, 1997), mentioned previously, is a bicultural approach that can be used by teachers and schools to improve behaviour and learning outcomes for Mãori students. Macfarlane proposes that it may be too much to expect teachers to achieve full bicultural competence, however, it is not unreasonable to expect then to strive for this. Indeed, a desire to aspire to bicultural competence clearly indicates an appreciation of the uniqueness of Māori students and their culture. The New Zealand Curriculum Framework (Ministry of Education, 1993), states that the framework "acknowledges also the value of the Treaty of Waitangi and of New Zealand's bicultural identity" (p. 1). The position of Glynn, Berryman, Walker, Reweti and O'Brien (2001) clearly recognises the importance of understanding and accepting the values of two traditions within bicultural Aotearoa New Zealand, and links directly to the partnership agreement of the Treaty of Waitangi. Tihe Mauri Ora (Ministry of Education, 1990) epitomises the essence of biculturalism, reminding teachers that respect for others, provision of equity for all and the acknowledgement of difference and diversity, are true indicators of a society which is mature and tolerant. If we, as a society, are to believe that we are embracing biculturalism, then we must honour, practise and live the ideals agreed to when, in 1840, two cultures came together at Waitangi.

The Treaty of Waitangi (Article 2) guarantees Mãori protection of their taonga (treasures - taonga such as the culture and the language. In honouring the tikanga, or intent, of the Treaty of Waitangi, teachers and educational professionals should ask the following questions: Does our organisation use Māori people to decorate a process that remains resolutely non-Mãori? What is the role of Māori staff within our school? What are the connections with our Mãori community? What training is available for our teachers and administrators on things Mãori? As a school, what do we believe biculturalism to be? Are our classrooms and school processes truly reflective of Māori and bicultural practices, values and understandings?'

Responses to these questions will provide the basis for schools to identify and address baseline issues. There is no easy solution. A determination to find passage through what may be challenging - sometimes even hostile - experiences, will lead to renewed understanding and commitment to creating culturally-safe schools. Listening to the voices of 
the Mãori students themselves is one of the integral factors throughout this process. The answer given by one senior Mãori student in a secondary school to Cavanagh's question "What it is like to be a Māori student in senior school?" was "most of the time the lights are turned off. The light comes on Tuesday afternoon at kapahaka". This student was considered by administrators at the school to be successful and presenting no behaviours of concern. However, her response clearly indicates that the definition of success should not be based on external and observable behaviours only. Implicit in her response is the notion that success in the classroom should not require them to leave their cultural identity at the school gate.

No-one can pretend that getting a consensus on creating culturally-safe schools is a simple task for school administrators and classroom teachers. However, the findings from the research studies referred to in this paper may serve to encourage schools to develop policies and programmes tailored to their own contexts and cultures. Restorative practices, the Hikairo Rationale, and the copious strategies inherent within the Educultural Wheel, are suggested as educational approaches to improve the quality of teaching for Mãori students. All these resources have an important role to play in teacher education programmes, special education programmes, professional development initiatives for teachers and resource teachers, and information materials for schools' governing bodies.

Te whitingà kia tata ka nobo

\section{Kia roa te putanga kē}

Let us work closer as a group

So that security and survival is ensured

Acknowledgements

This team of writers is grateful for the support received from their respective organisations, the University of Waikato and the New Zealand Ministry of Education. A primary site was the Raglan Area School and we are grateful for the open-door policy that they maintained over many weeks of research activity. Finally, we extend our thanks to the Fulbright Foundation for their contributions toward bringing peoples, cultures or nations to greater understanding of others.

\section{References}

Ark, T. V. (2002). The case for small high schools. Educational Leadership, 59(5), 55-59

Bateman, S. (2003). Te Kupenga o te Manaaki: The net of replenishment: A collaborative process for data gathering and assessment. Hamilton, New Zealand: Author.

Bird, L. \& Drewery, W. (2000). Human Development in Aotearoa: A journey through life. Auckland: McGraw-Hill.

Bishop, R. (1996). Addressing issues of self-determination and legitimation on kaupapa Māori research. In B. Webber (Ed.). He Paepae Korero, research perspectives in Merori education (pp. 143-160). Wellington: New Zealand Council for Educational Research.

Bishop, R. (2005). Freeing ourselves from neocolonial domination in research: A kaupapa Māori approach to creating knowledge. In N. K. Denzin \& Y. S. Lincoln (Eds.), The Sage handbook of qualitative research (3rd ed., pp. 109-138). Thousand 0aks, CA: Sage.

Bishop, R., \& Glynn, T. (1999). Culture counts: Changing power relations in education. Palmerston North, New Zealand: Dunmore Press.

Bishop, R., Berryman, M., Richardson, C., \& Tiakiwai, S. (2003). Te Kotahitanga: The experiences of year 9 and 10 Merori students in mainstream classrooms. Final report to the Ministry of Education, Wellington, New Zealand [Electronic version]. Retrieved 5 November, 2007, from http:// www.minedu.govt.nz/goto/tekotahitanga.

Bishop, R., Berryman, M., Cavanagh, T., \& Walker, R. (2006, April). Te Kotahitanga: Meri epistemology and school reform. Paper presented at an Invited Symposium for Division K: Teaching and Teacher Education at the American Educational Research Association Annual Meeting, San Francisco, California.

Bronfenbrenner, U. (1979). The ecology of human development: Experiments by nature and design. Cambridge, MA: Harvard University Press.

Bruner, J. (1996). The culture of education. London: Harvard University Press.

Cathcart, R. (1994). They're not bringing my brain out introducing the REACH model for working with exceptional children. Auckland, New Zealand: Reach Publications.

Cavanagh, T. (2004, October). Criminalising our schools: Effects on caring and nurturing teachers. Paper presented at the Invited Address: School of Education, University of Waikato, Hamilton, New Zealand.

Cavanagh, T. (2005). Constructing ethnographic relationships: Reflections on key issues and struggles in the field. Waikato Journal of Education, 11(1), $27-42$.

Durie, M. (1994). Whaiora: Maori health development. Auckland, New Zealand: Oxford University Press.

Glasser, W. (1975). Reality therapy: An approach to psychiatry. New York, NY: Harper \& Row.

Glynn, T., Berryman, M., Atvars, K., \& Harawira, W. (1997). Hei Awbina Maori: A bome and school behaviour programme. Report to the Ministry of Education, Wellington, Ministry of Education.

Glynn, T., Berryman, M., Bidois, P., Atvars, K., Duffull, T., \& Horne, J. (1997). Involving children in research: The Hei Awhina Māori research project. Childrens Issues: Journal of the Children's Issues Centre, 1(1), 37-43.

Glynn, T., Berryman, M., Walker, R., Reweti, M., \& 0'Brien, K. (2001). Partnerships with indigenous people: modifying the cultural mainstream. Keynote Address at the Partnerships in Education Psychology Conference, Brisbane, Queensland.

Glynn, T., Wearmouth, J., \& Berryman, M. (2005). Supporting students with literacy difficulties: A responsive approach. London: McGraw-Hill Education.

Holmes, J. (1982). Language for learning: Education in the multicultural school. Wellington, New Zealand: Department of Education.

Hooper, S., Winslade, J., Drewery, W., Monk, G., \& Macfarlane, A. (1999, July). School and family group conferences: Te Hui Whakatika (a time for making amends). Paper presented at the Keeping Young People in School Summit Conference on Truancy, Suspensions and Effective Alternatives, Auckland, New Zealand. 
Macfarlane, A. (1997). The Hikairo Rationale teaching students with emotional and behavioural difficulties: A bicultural approach. Waikato Journal of Education, 3, 153-168.

Macfarlane, A. (1998, July). Piki Ake Te Tikanga: Culture counts in special education. Paper presented at the Teacher education: Challenge and creativity, 28th Annual Conference, Australian Teacher Education Association, Melbourne, Victoria.

Macfarlane, A. (2000). The value of Mäori ecologies in special education. In D. Fraser, R. Moltzen \& K. Ryba (Eds.), Special education in Aotearoa New Zealand (pp. 77-98). Palmerston North, New Zealand: Dunmore Press.

Macfarlane, A. (2004). Kia hiwa ra! Listen to culture: Merori students' plea to educators. Wellington, New Zealand: New Zealand Council for Educational Research.

Macfarlane, A., \& Bateman, S. (2005, August). Connecting with culture: The critical element in diverse classrooms. Paper presented at the Inclusive and Supportive Education Congress International Special Education Conference (ISEC), Inclusion: Celebrating diversity, Glasgow, Scotland.

Macfarlane, A., \& Glynn, T. (1998, December). Mana Meori in the professional development programme for resource teachers: Learning and bebaviour. Paper presented at the New Zealand Association for Research in Education (NZARE) 20th Annual Conference, Dunedin, New Zealand.

Metge, J. (1984). Learning and teaching: He Tikanga Maori. Wellington, New Zealand: Māori and Islands Division, Department of Education.

McNaughton, S. (2002). Meeting of minds. Wellington, New Zealand: Learning Media.

Ministry of Education. (1990). Tihe Mauri Ora!: Merori language syllabus for schools. Wellington, New Zealand: Learning Media.

Ministry of Education (1993). The New Zealand Curriculum Framework: Te Anga Marautanga o Aotearoa. Wellington: Ministry of Education.

Noddings, N. (2002). Educating moral people: An alternative to character education. New York, NY: Teachers College Press.

Penetito, W. (2004, November). Theorising a "place-based education": Abakoa kai tabi, tera a roto te habae ke ra. Keynote address presented at the New Zealand Association for Research in Education (NZARE) National Conference, Wellington, New Zealand.

Rangihau, J. (1975). Being Māori. In M. King (Ed.), Te ao huriburi, the world moves on: Aspects of Māoritanga (pp. 183-190). Auckland, New Zealand: Hicks Smiths.

Vygotsky, L. (1978). Mind and society. Cambridge, MA: Harvard University Press.

Wearmouth, J., McKinney, R., \& Glynn, T. (in press). Restorative justice in schools: A New Zealand example. Educational Research.

Wearmouth, J., Glynn, T., \& Berryman, M. (2005). Perspectives on student behaviours in schools: Exploring theory and developing practice. Milton Park: Routledge.

\section{About the authors}

Angus Hikairo Macfarlane is of the Te Arawa tribe of the central North Island of New Zealand. He is an experienced educator and practitioner and has been an advisor for the Ministry of Education. The thrust of his research is concerned with the exploration of cultural concepts and theories that affect classroom practice. In 2003 he was awarded the inaugural Research Fellowship by the New Zealand Council for Educational Research. In 2004 he was a recipient of a Tohu Paerangi, a presentation made at the annual Māori Academic Excellence Awards ceremony. Dr Macfarlane coordinates postgraduate papers in special education at the University of Waikato.

Ted Glynn is Foundation Professor of Teacher Education at the University of Waikato and a Fellow of the Royal Society of New Zealand. He has a wide background in applied behaviour analysis, inclusive education, and Māori and bilingual education. He helped to pioneer the Pause Prompt Praise reading tutoring procedures, and the Māori language version, Tatari Tautoko Tauawhi. He is a member of the New Zealand Universities Consortium which produced the Resource Teachers: Learning and Behaviour (RTLB) professional development programme - part of the New Zealand Government's Special Education 2000 policy initiative. Professor Glynn is a member of the Ministry of Education (Group Special Education) Poutama Pounamu Education Research Centre in Tauranga.

Tom Cavanagh is a Senior Research Fellow for the Wilf Malcolm Institute for Educational Research at the University of Waikato. He is responsible for research support for Te Kotahitanga, professional development project focused on raising the achievement of Mãori students. Tom originally came to New Zealand on a Fulbright Fellowship in 2004. He specializes in research methodology, and his research interests focus on developing a culture of care in schools using restorative practices to respond to problems related to student behaviour and a culturally-responsive pedagogy of relations in classrooms.

Sonja Bateman affiliates to the Ngai Tahu tribe of the South Island and is an experienced special educator and practitioner. Her passion for improving educational outcomes for at-risk students has seen her move from classroom teacher, to Resource Teacher of Learning and Behaviour (RTLB), to her present position of Practice Leader: Services to Māori - a national position - for the Ministry of Education. Sonja has co-authored and copresented papers on cultural and behavioural issues, and has facilitated professional development seminars for teachers and special educators who are seeking to explore more appropriate strategies for managing challenging students. Her work and current research has a focus on informed thinking and guidance that is intended to enhance professional service delivery to, and outcomes achieved by, learners who are Mãori. 
Glossary

\begin{tabular}{|c|c|}
\hline Aotearoa & $\begin{array}{l}\text { original name for New } \\
\text { Zealand }\end{array}$ \\
\hline aroha & love, compassion \\
\hline Awhinatia & $\begin{array}{l}\text { helping process, } \\
\text { interventions }\end{array}$ \\
\hline haka & $\begin{array}{l}\text { ardent and animated } \\
\text { dance with chant }\end{array}$ \\
\hline hapũ & sub-tribe \\
\hline Hei Awhina Mātua & $\begin{array}{l}\text { a collaborative behaviour } \\
\text { management programme }\end{array}$ \\
\hline Hikairo & renowned ancestor \\
\hline Huakina mai & opening doorways \\
\hline I runga $\mathrm{i}$ te manaaki & pastoral care \\
\hline ihi & assertiveness \\
\hline iwi & tribe \\
\hline kai & food, sustenance \\
\hline kapahaka & $\begin{array}{l}\text { a Mãori performing arts } \\
\text { group }\end{array}$ \\
\hline karakia & prayer, incantation \\
\hline kaumātua & $\begin{array}{l}\text { older people in Māori } \\
\text { society }\end{array}$ \\
\hline kaupapa Mãori & $\begin{array}{l}\text { a Mãori approach, a } \\
\text { Mãori philosophy }\end{array}$ \\
\hline kawanatanga & governorship \\
\hline koha & unconditional gift \\
\hline kotahitanga & unity, bonding \\
\hline manaakitanga & ethos of care \\
\hline Mãori & Indigenous people \\
\hline Mãoritanga & Māoriness, being Mãori \\
\hline mātua & parents \\
\hline mihi & $\begin{array}{l}\text { culturally appropriate } \\
\text { greeting(s) }\end{array}$ \\
\hline oranga & a vision of well-being \\
\hline Pākehā & $\begin{array}{l}\text { person of European } \\
\text { ancestry }\end{array}$ \\
\hline Papatuanuku & Mother Earth \\
\hline pono & integrity \\
\hline Poutama Pounamu & $\begin{array}{l}\text { Ministry of Education } \\
\text { Research Centre }\end{array}$ \\
\hline powhiri & formal welcome \\
\hline Pumanawatanga & a beating heart \\
\hline Rangatiratanga & self-determination \\
\hline Raranga & weaving process \\
\hline Taha hinengaro & cognitive aspect \\
\hline Taha tinana & physical aspect \\
\hline Taha wairua & spiritual aspect \\
\hline Taha whānau & family aspect \\
\hline tangata whenua & Indigenous people \\
\hline taonga & treasures, resources \\
\hline Te Kotahitanga & \begin{tabular}{|l|} 
a professional \\
development project
\end{tabular} \\
\hline
\end{tabular}

\begin{tabular}{|l|l|}
\hline Te Kupenga o te Manaaki & $\begin{array}{l}\text { supportive process for } \\
\text { assessment and planning }\end{array}$ \\
\hline te reo Mãori & Mãori language \\
\hline Te Whare Tapa Whã & $\begin{array}{l}\text { an holistic framework in } \\
\text { health and education }\end{array}$ \\
\hline Te wiki o te reo Mãori & Mãori language week \\
\hline tika & fairness \\
\hline tikanga & custom(s) \\
\hline tikanga Mãori & $\begin{array}{l}\text { values beliefs and } \\
\text { practices held by Mãori } \\
\text { people }\end{array}$ \\
\hline Te Hui Whakatika & restorative practice \\
\hline tuakana-teina & cross-age mentorship \\
\hline waiata & song \\
\hline whakatau & informal welcome \\
\hline whakatauki & proverb \\
\hline whakawhanaungatanga & $\begin{array}{l}\text { the process of building } \\
\text { relationships }\end{array}$ \\
\hline whānau & extended family \\
\hline whanaungatanga & relationships \\
\hline
\end{tabular}



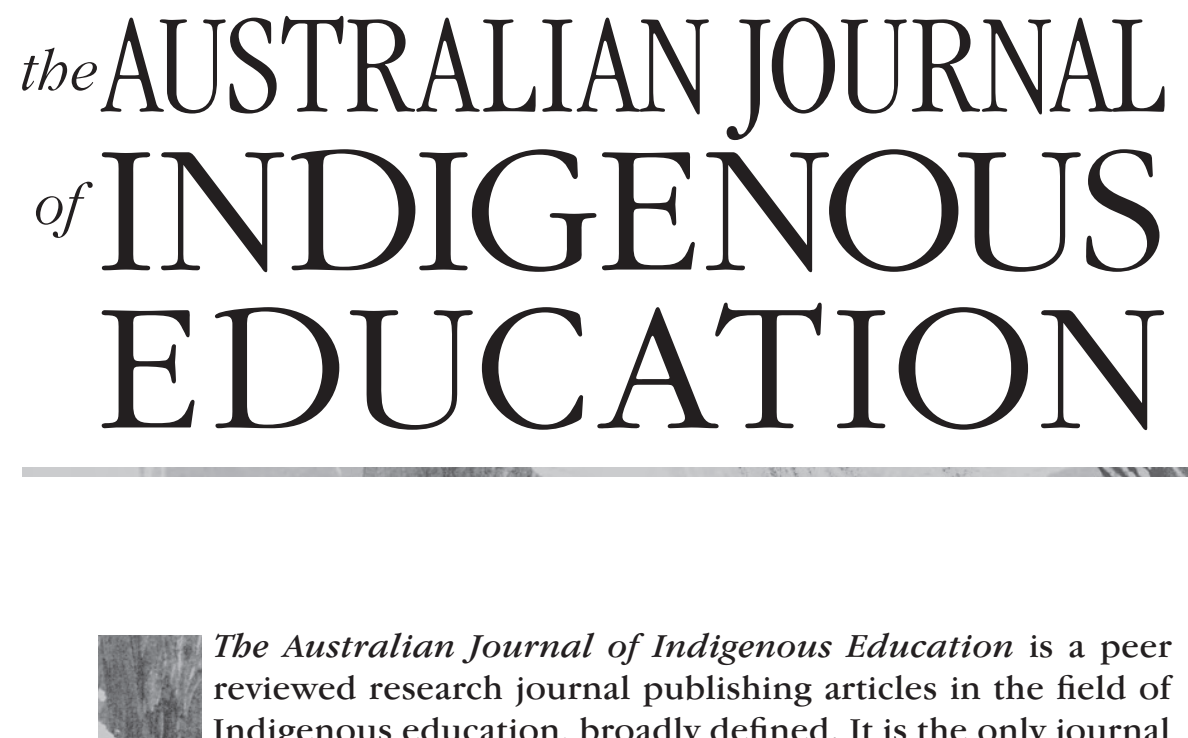

The Australian Journal of Indigenous Education is a peer reviewed research journal publishing articles in the field of

Indigenous education, broadly defined. It is the only journal for educators devoted specifically to issues of practice, pedagogy and policy in Indigenous education in Australia. The journal has an international audience and is highly valued by its readers as a reliable source of information on Indigenous education issues Contributions on the participation of Indigenous people in education and training; equitable and appropriate access and achievement of Indigenous people in education and training; and the teaching of Indigenous studies, cultures and languages to both Indigenous and non-Indigenous students are encouraged. Notes to Contributors can be found at the back of each issue. The journal is published by the Aboriginal and Torres Strait Islander Studies Unit at the University of Queensland, under the strategic management and with the support of the Unit Director, Michael Williams.

Editors: Jackie Huggins \& Elizabeth Mackinlay

Managing Editor: Sean Ulm

Book Review Editor: Sean Ulm

Administrative Assistants: Kate Barney \& Jan Stewart

Grapbic Design: Lovehate Design

Printing: Printpoint Australia Pty Ltd

Artwork: Adapted from Jungle Vine (2002)

by Macsen Ja-wukanyi Chalmers

All correspondence and submissions should be addressed to:

The Editors

The Australian Journal of Indigenous Education

Aboriginal and Torres Strait Islander Studies Unit

The University of Queensland

Brisbane QLD 4072

AUSTRALIA

Email: ajie@uq.edu.au

URL: http://www.atsis.uq.edu.au/ajie/

The views expressed in this journal are not necessarily those of the Editors or Publisher.

(C) Aboriginal and Torres Strait Islander Studies Unit

The University of Queensland, 2007

ISSN 1326-0111

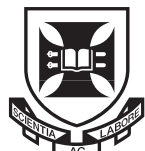

THE UNIVERSITY OF QUEENSLAND

A U S T R A L I A 


\section{TABLE of CONTENTS}

EDITORIAL

Elizabeth Mackinlay \& Jackie Huggins

WHERE DO WE LOOK NOW?

The Future of Research in Indigenous Australian Education

Neil Harrison

CLIMBING the EDUCATIONAL MOUNTAIN:

A Metaphor for Real Culture Change for Indigenous Students in Remote Schools Robyn Hewitson

INCLUSIVE and EMPOWERING DISCOURSE in an EARLY CHILDHOOD LITERACY CLASSROOM with INDIGENOUS STUDENTS

Anne Thwaite

WORKING PRODUCTIVELY with INDIGENOUS COMMUNITIES:

Mungullah Best Start Playgroup

Libby Lee \& Andrew Thompson

COMMUNITY INVOLVEMENT and EDUCATION in the 1991-2000 AUSTRALIAN RECONCILIATION PROCESS Andrew Gunstone

PURSING INDIGENOUS-INCLUSIVE CURRICULUM in SOCIAL WORK TERTIARY EDUCATION:

Feeling my Way as a Non-Indigenous Educator

Susan Gair

PERFORMATIVE PEDAGOGY and the CREATION of DESIRE:

The Indigenous Athlete/Role Model and Implications for Learning

Stella Coram

CREATING CULTURALLY-SAFE SCHOOLS for MĀORI STUDENTS

Angus Macfarlane, Ted Glynn, Tom Cavanagh \& Sonja Bateman

TAKING OWNERSHIP:

The Implementation of a Non-Aboriginal Early Education Programme for On-Reserve Children

Michelle Beatch \& Lucy Le Mare

ABORIGINAL UNIVERSITY STUDENT SUCCESS in BRITISH COLUMBIA, CANADA:

Time for Action

James Alan Oloo

INFLUENCES PRECEDING "NUNATSIAVUT" SELF-DETERMINATION:

Historical, Political and Educational Influences on the People of Northern Labrador (Canada)

Kirk David Anderson

BOOK REVIEWS

Australian Indigenous Knowledge and Libraries

Sin-E-Anne

Treading Lightly: The Hidden Wisdom of the World's Oldest People

Information Technology and Indigenous People

Sharing Spaces: Indigenous and Non-Indigenous Responses to Story, Country and Rights 119

Sovereign Subjects: Indigenous Sovereignty Matters 120

Trustees On Trial: Recovering the Stolen Wages 121

Aboriginal Darwin: A Guide to Exploring Important Sites of the Past and Present 123

Disturbances and Dislocations: Understanding Teaching and Learning Experiences in Indigenous

Australian Women's Music and Dance

Social Determinants of Indigenous Health

Disciplining the Savages, Savaging the Disciplines

Rob Riley: An Aboriginal Leader's Quest for Justice 